\title{
"The influence of central bank monetary policy announcements on cryptocurrency return volatility"
}

\begin{tabular}{|c|c|}
\hline AUTHORS & $\begin{array}{l}\text { Shaen Corbet } \\
\text { Grace McHugh } \\
\text { Andrew Meegan }\end{array}$ \\
\hline ARTICLE INFO & $\begin{array}{l}\text { Shaen Corbet, Grace McHugh and Andrew Meegan (2017). The influence of } \\
\text { central bank monetary policy announcements on cryptocurrency return volatility. } \\
\text { Investment Management and Financial Innovations, 14(4), 60-72. } \\
\text { doi:10.21511/imfi.14(4).2017.07 }\end{array}$ \\
\hline DOI & http://dx.doi.org/10.21511/imfi.14(4).2017.07 \\
\hline RELEASED ON & Friday, 15 December 2017 \\
\hline RECEIVED ON & Thursday, 24 August 2017 \\
\hline \multirow[t]{2}{*}{ ACCEPTED ON } & Monday, 27 November 2017 \\
\hline & $((c))$ EY \\
\hline LICENSE & $\begin{array}{l}\text { This work is licensed under a Creative Commons Attribution } 4.0 \text { International } \\
\text { License }\end{array}$ \\
\hline JOURNAL & "Investment Management and Financial Innovations" \\
\hline ISSN PRINT & $1810-4967$ \\
\hline ISSN ONLINE & $1812-9358$ \\
\hline PUBLISHER & LLC “Consulting Publishing Company "Business Perspectives" \\
\hline FOUNDER & LLC "Consulting Publishing Company "Business Perspectives" \\
\hline
\end{tabular}

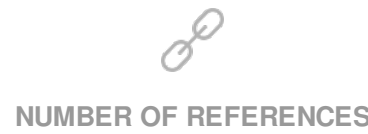

40

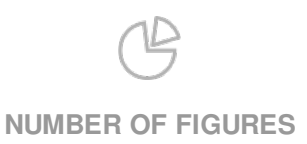

6

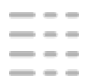

NUMBER OF TABLES

4

(C) The author(s) 2023. This publication is an open access article. 


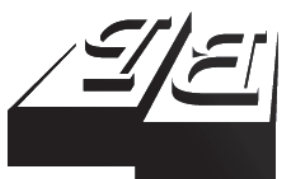

BUSINESS PERSPECTIVES

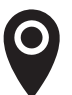

LLC "CPC "Business Perspectives" Hryhorii Skovoroda lane, 10, Sumy, 40022, Ukraine

www.businessperspectives.org

Received on: $24^{\text {th }}$ of August, 2017 Accepted on: $27^{\text {th }}$ of November, 2017

(c) Shaen Corbet, Grace McHugh, Andrew Meegan, 2017

Shaen Corbet, Dr., Assistant Professor of Finance, DCU Business School, Dublin City University (DCU), Ireland.

Grace McHugh, DCU Business School, Dublin City University (DCU), Ireland.

Andrew Meegan, Ph.D. Student, DCU Business School, Dublin City University (DCU), Ireland.

\section{(ㄷ) (1)}

This is an Open Access article, distributed under the terms of the Creative Commons Attribution 4.0 International license, which permits unrestricted re-use, distribution, and reproduction in any medium, provided the original work is properly cited.

\section{THE INFLUENCE OF CENTRAL BANK MONETARY POLICY ANNOUNCEMENTS ON CRYPTOCURRENCY RETURN VOLATILITY}

\begin{abstract}
The emergence of Bitcoin in 2009 has received considerable attention surrounding the validity of cryptocurrencies as a viable, and in some jurisdictions, a legal currency alternative. Despite widespread concern that these cryptocurrencies are fostering the environment within which a substantial bubble can occur, it is important to analyze whether these new assets are behaving similarly to major international currencies. This paper investigates the effects of international monetary policy changes on bitcoin returns using a GARCH (1.1) estimation model. The results indicate that monetary policy decisions based on interest rates taken by the Federal Open Market Committee in the United States significantly impact upon bitcoin returns. After controlling for international effects, we find significant evidence of volatility effects driven by United States, European Union, United Kingdom and Japanese quantitative easing announcements. These results show that, despite its nature and ideals, bitcoin seems to be subject to the same economic factors as traditional fiat currencies, and is not entirely unaffected by government policies. This result has implications for investors using bitcoin as a hedging or diversification tool. In addition, we contribute to the existing debate regarding the classification of bitcoin as an asset class, by illustrating that bitcoin volatility exhibits various reactions that bear resemblance to both currency pairs and storeof-value assets.
\end{abstract}

\section{Keywords}

bitcoin, cryptocurrency, market volatility, monetary policy announcements, portfolio diversification

\section{JEL Classification C32, C58, G15}

\section{INTRODUCTION}

Bitcoin is becoming increasingly popular and relevant in both academic research and the widespread financial system. The increasing use of blockchain technology, and its potential widespread use in the future means that research is necessary to examine the reaction of digital assets to external macroeconomic factors, compared to that of traditional currencies and assets.

Bitcoin is a peer-to-peer digital asset, which claims to be decentralized and independent of monetary authority influence, created in 2009 by Satoshi Nakamoto ${ }^{1}$. Transactions take place directly between users, and are verified by network nodes. To overcome the traditional "double-spending" 2 problem, each transaction must be cryptographically

1 Satoshi Nakamoto is the pseudonym used by the programmer, or group of programmers, who created bitcoin. Despite much speculation, and several claims by individuals, the identify of Nakamoto remains a mystery.

2 Double-spending is a problem, unique to digital assets, in which the same coin or token can be spent several times. 
verified by a network node, or "miner" (Kroll et al., (2013) who provide a detailed description of the mining process). Miners add verified transactions to a publicly distributed ledger, or blockchain, and are incentivized to do so by the reward of transaction fees and new bitcoins. New bitcoins are created every 10 minutes via this mining process, and will continue to do so until the full supply of 21 million bitcoins has been issued. In this way, unlike traditional fiat currencies, bitcoin is a deflationary asset.

If bitcoin's claims to be a decentralized currency independent of any government influence are true, we would expect government policy interventions to have no impact on the volatility of such returns. We use a GARCH (1.1) specification to model the effect of government policy announcements on bitcoin returns volatility, and determine whether said announcements generate a significant observed change in volatility.

A number of previous studies have focused on the classification of bitcoin as an asset class and questioned whether it most resembles a currency (similar to the US dollar) or a store of value (Gold). In addition, the touting of bitcoin as the "virtual gold" has led to its increasing use as a diversification tool by investors. To examine such claims, we use an OLS methodology to estimate the effects of a number of external variables on bitcoin returns volatility. Specifically, we use UK and European market proxies, exchange rate pairs, commodity proxies (representing each of the two potential asset classes: currency and store-of-value) and a number of day-of-the-week indicator variables.

Our results suggest that monetary policy decisions and announcements have a significant volatility effect on bitcoin returns. Monetary policy decisions based on interest rates taken by the Federal Open Market Committee in the United States are found to have a significant impact on bitcoin volatility. After controlling for international effects, we find significant evidence of volatility effects driven by United States, European Union, United Kingdom and Japanese quantitative easing announcements. Increases in such QE programes had strong significantly positive impacts on bitcoin returns volatility.

Our findings suggest that bitcoin is not immune to spillover effects from international policy maker decisions - a result which is somewhat at odds with its decentralized nature. These findings have implications for users of bitcoin, for investors in currencies building risk management strategies and for policy makers themselves. Bitcoin and broader cryptocurrencies appear to have developed significant behavioral characteristics, similar to major international assets such as broad cross-currencies, equities and commodities. Our findings add further weight to the argument that bitcoin occupies a unique asset classification (Dyhrberg, 2016) somewhere between a functioning currency and a traditional store-of-value asset.

The remainder of the paper is organized as follows. Section 1 presents a review of previous literature. Section 2 presents the data and methodology used. Section 3 discusses the empirical results. Final section concludes and discusses the relevance of our findings.

\section{PREVIOUS LITERATURE}

The bitcoin market has increased dramatically over the last four years. As of August 2017, the total market cap had surpassed $\$ 55$ billion, with daily trading volume regularly exceeding $\$ 1$ billion. Although initially traded primarily through USD, bitcoin trading via Chinese yuan increased dramatically from 2014 to early 2017 as illustrated in Figure 1. This increase may be attributed to the surge in bitcoin mines (and mining pools) located throughout China (due to low electricity costs), and the large control they exert on the network. The resurgence in US dollars that has been seen throughout 2017 can be attributed to an increased public awareness of bitcoin throughout the United States due, in part, to increased media coverage.

The increased mainstream coverage of bitcoin has led to an influx of non-technical, new entrants to the market. Prior to this increase, the majority of bitcoin users were considered to be either computer programming enthusiasts or individuals engaging in illegal activity (Yelowitz \& Wilson, 2015). 


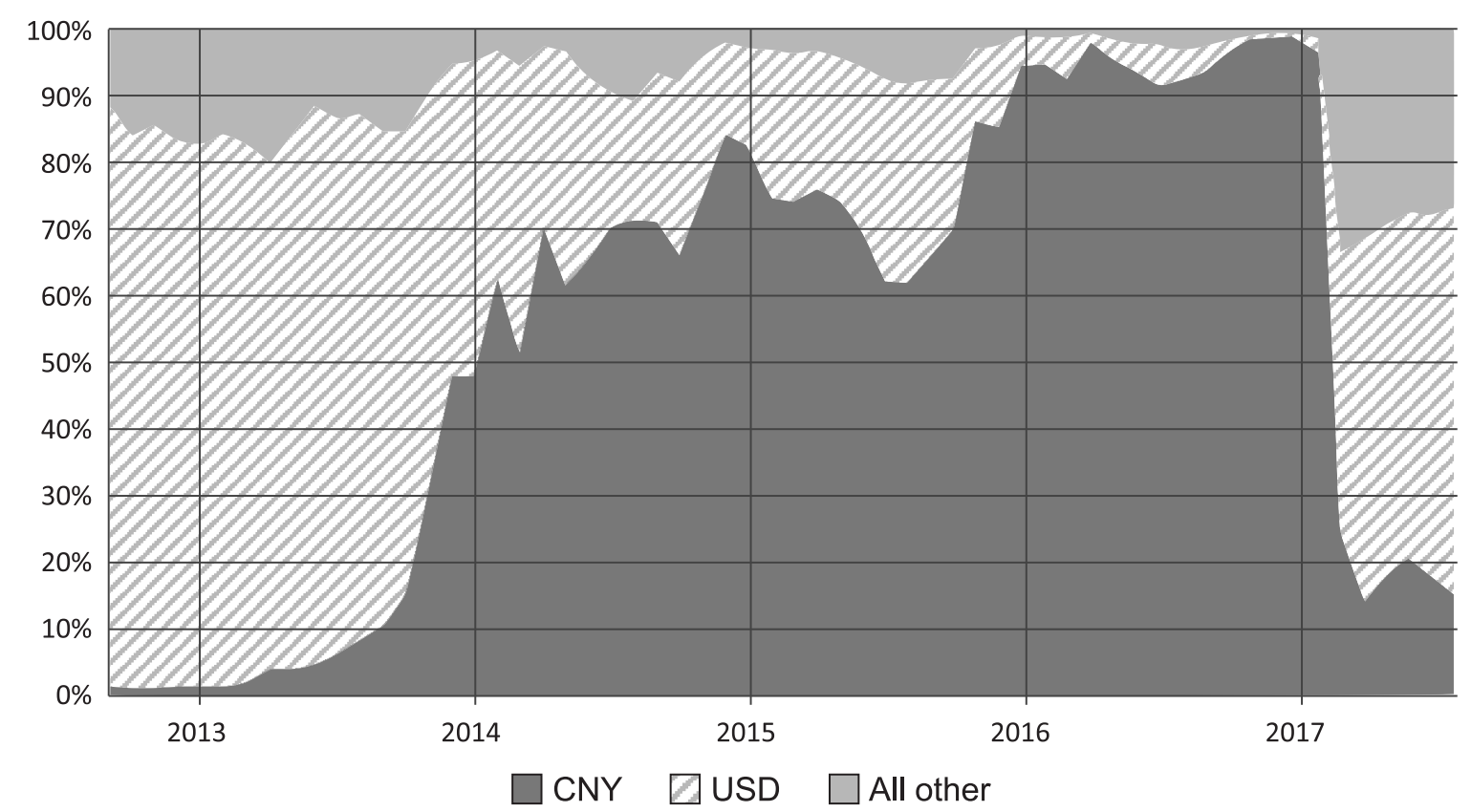

Figure 1. Percentage of total bitcoin trading from August 2012 to August 2017

The influx of first-time buyers may also be attributed to the increase in user-friendly methods of purchase. Sites such as coinbase.com have made it relatively uncomplicated for someone with no technical knowledge, or prior experience, to purchase bitcoin. Despite this, most daily trading is still conducted on exchange sites, the largest 3 being bittex, bithumb and bitfinex.com. Price increases are driven by traditional fundamental factors, namely trade usage, price level, money supply, as well as periods of explosive price increases (Kristoufek, 2015). An increase in investors' interest during these times of large price increases suggests an increase in speculative buyers entering the market, motivated by a "fear of missing out".

Bitcoin is a decentralized peer-to-peer network, which is not governed by any official centralized issuing authority (Ron \& Shamir, 2012). As such, Karlstrom (2014) notes a number of unique characteristics which differentiate bitcoin from traditional fiat currencies $\left.{ }^{3}: 1\right)$ the money supply is controlled by an algorithm, the structure of which is in the public domain, and is independent of central bank monetary policy; 2) verification of transactions is decentralized and non-hierarchical; 3) electronic wallets are not directly connected to their respective owners by identifiable information.

There have been numerous attempts to determine the particular asset class under which bitcoin falls, with many studies questioning whether bitcoin bears greater resemblance to a currency (US dollars) or a store of value (gold). Swartz (2014) defines a currency as "a coin, government note or bank note that circulates as a medium of exchange, unit of account and store of value". Swartz (2014) doubted that bitcoins could successfully function as such due to their complicated nature and the lack of viable ways in which to spend them. Slow transaction times, and the increasingly high miner's fees associated with them, have prevented bitcoin from being adopted as a viable day-to-day currency. However, a number of improvements ${ }^{4,5}$ appear imminent which could overcome these difficulties.

3 Fiat money refers to any currency which has been established and declared legal tender by a government, but is not backed by any physical commodity.

4 The lightning network proposes to implement hashed timelock contracts (HTLCs) with bi-directional payment channels. This would dramatically increase the speed of bitcoin payments, as well as reducing the amount of payments that must be processed by full nodes on the network.

5 Bitcoin blocks are currently limited to 1MB in size, placing a premium on the transactions that are included in each block. A number of potential strategies have been proposed (BIP 148/Segwit2X) to increase the block size. This increase of block size will lead a reduction in transaction (miners) fees. 
Lo and Wang (2014) found that a large proportion of bitcoins obtained in the period prior to May 2012 were not spent within three months of receipt, suggesting that they were held more as a store of value than as a medium of exchange. Dyhrberg (2016) attempted to classify bitcoin by performing a GARCH volatility analysis on the returns of all three assets - gold, US dollars and bitcoin. Bitcoin is found to display a number of similarities to both oil and gold. It not only displays a reaction to Federal Fund rate changes (as would be expected by a currency), but also displays hedging capabilities, and a symmetric reaction to news (characteristics that would traditionally be associated with gold).

The impact of monetary policy announcement "news" affects asset pricing theory in a variety of ways. Birz and Lott (2011) find that it directly affects the level of consumption or the investment opportunity set. Geman, Madan, and Yor (2000) find that discontinuity in the information flow in relation to the arrival of news drives the jumps in volatility during the pricing process, with the macroeconomic events generating considerable interest, as they provide an expectation of the general economic conditions and future outlook. Eun and Shim (1989) use vector autoregression models (VARs) to observe the size of multiple countries' volatility channels, identifying the US as the largest.

Belgacem and Lahini (2012) used a DCC-GARCH model to compare new effects in the US and European bond and stock markets, finding a significant news effects sourced in the US. The use of a GARCH specification to investigate volatility impact has been utilized in a number of studies (Rangel, 2010; Egert \& Kocenda, 2013). The model specifications used in this analysis bear most resemblance to the work of Bomfim (2003) and Lobo (2002), in which they used augmented GARCH and EGARCH models, respectively, to investigate volatility impacts.

Glick and Leduc (2012) observed that commodity prices are forward-looking variables that respond rapidly to worldwide economic news. In the days following a monetary policy announcement, commodity prices were observed to fall, the fall being significantly larger when the monetary policy announcement was deemed to be negative. Lobo (2000), Bernanke and Kuttner (2005), and Chulia et al. (2010) also observed an asymmetric relationship between monetary policy and stock market volatility; similarly find that the level of volatility is dependent on whether the monetary policy changes are positive or negative. D'Amico et al. (2012) found that, although quantitative easing and interest rate policies differ, they share the same purposes of affecting long-term interest rates by way of the term-premium component of the assets included in these policies.

\section{DATA AND METHODOLOGY}

Our sample consists of daily bitcoin closing prices, ranging from 19 July 2010 to 29 April 2016 (1,509 observations). To separate international effects within the GARCH methodology, we have included the returns of the United States stock markets in the form of the S\&P500, the returns on European equities through the EUROSTOXX 50 and currency effects through the trade-weighted index of the domestic currency against a basket ${ }^{6}$ of US dollar, euro, yen and sterling. The multiple international crises and terrorism events during the period of the sample are isolated by the inclusion of variables representing oil and gold ${ }^{7}$ as used by Corbet and Twomey (2014), Corbet and Larkin (2017). All other variables are sourced from Bloomberg. The inclusion of these currency and commodity variables allows investor behavior, such as flights to safety, to be isolated. Bitcoin returns have been shown to be affected by both good and bad news (Kristoufek, 2014). This suggests that the arrival of "news" in the form of FOMC announcements should have a significant effect on bitcoin volatility. The expected effect of such announcements is as follows: following a FOMC announcement, a fall in government and corporate bond yields is expected. This encourages investors to seek riskier alternative investment classes, and should push alternative asset values and volatility upwards (Meaning \& Zhu, 2011; Joyce et al., 2011).

7 The price of oil is represented by the West Texas Intermediate price - a grade of light crude oil frequently used as an oil benchmark. We use daily spot price levels to measure the changing price of gold. 
Table 1. Descriptive statistics: asset returns

\begin{tabular}{|c|c|c|c|c|c|c|c|c|}
\hline Variable & Mean & Max & Min & SD & Skewness & Kurtosis & $\begin{array}{c}\text { Jarque- } \\
\text { Bera }\end{array}$ & ADF \\
\hline Bitcoin & 0.0055 & 0.5170 & -0.6093 & 0.0737 & -0.3371 & 16.1060 & $1128.695^{* * *}$ & $16.189^{* * *}$ \\
\hline EUROSTOXX 50 & 0.0004 & 0.0521 & -0.0599 & 0.0129 & -0.2057 & 5.1344 & $291.936^{* * *}$ & $19.357^{* * *}$ \\
\hline S\&P500 & 0.0003 & 0.0415 & -0.0571 & 0.0088 & -0.4048 & 7.0629 & $948.836^{* * *}$ & $29.841^{* * *}$ \\
\hline USD-EU & 0.0000 & 0.0241 & -0.0301 & 0.0060 & -0.0028 & 4.5243 & $146.682^{* * *}$ & $14.668^{* * *}$ \\
\hline UDS-GB & 0.0000 & 0.0179 & -0.0155 & 0.0047 & -0.0581 & 3.5531 & $197.900^{* * *}$ & $18.837^{* * *}$ \\
\hline USD-JP & 0.0002 & 0.0349 & -0.0305 & 0.0058 & -0.2423 & 6.9534 & $1013.036^{* * *}$ & $15.801^{* * *}$ \\
\hline WTI crude oil spot & -0.0003 & 0.1162 & -0.0907 & 0.0202 & 0.2320 & 6.6572 & $786.634^{* * *}$ & $14.833^{* * *}$ \\
\hline Gold spot & 0.0000 & 0.0406 & -0.0951 & 0.0107 & -0.7342 & 9.1773 & $2566.443^{* * *}$ & $23.283^{* * *}$ \\
\hline
\end{tabular}

Notes: numbers in parentheses indicate the standard errors. ${ }^{* * *},{ }^{* *}$ and ${ }^{*}$ indicate the significance level at the $1 \%, 5 \%$ and $10 \%$ levels, respectively.

The continuously compounded daily returns for the data are computed as $r_{t}=100 \cdot \ln p_{t} / p_{t-1} \cdot p_{t}$ is the stock price at time $t$, and $p_{t-1}$ is the stock price at time $t-1$. Table 1 reports the descriptive statistics for the continuously compounded returns. The return distribution is negatively skewed for all variables with the exception of oil returns. The behavior of bitcoin's daily returns in 2010 and 2011 appear to instil significant variance in the return distribution. This is largely attributed to the relative illiquidity found in the bitcoin market in this time period ${ }^{8}$ as seen in Figure 1.
The individual central bank monetary decisions are reported from the minutes of the meetings that decided upon the interest rate and quantitative easing actions taken. Those central banks included and their respective jurisdictions include: the Federal Open Market Committee (FOMC) in the US, the Governing Council of the European Central Bank (ECB), the Monetary Policy Committee of the Bank of England (BoE) and the Policy Board of the Bank of Japan (BOJ). The number of announcement and segregation of announcement type are presented in Table 2

8 The relatively large value of kurtosis statistics suggests that the underlying data are leptokurtic, or fat-tailed and sharply peaked about the mean when compared with the normal distribution.

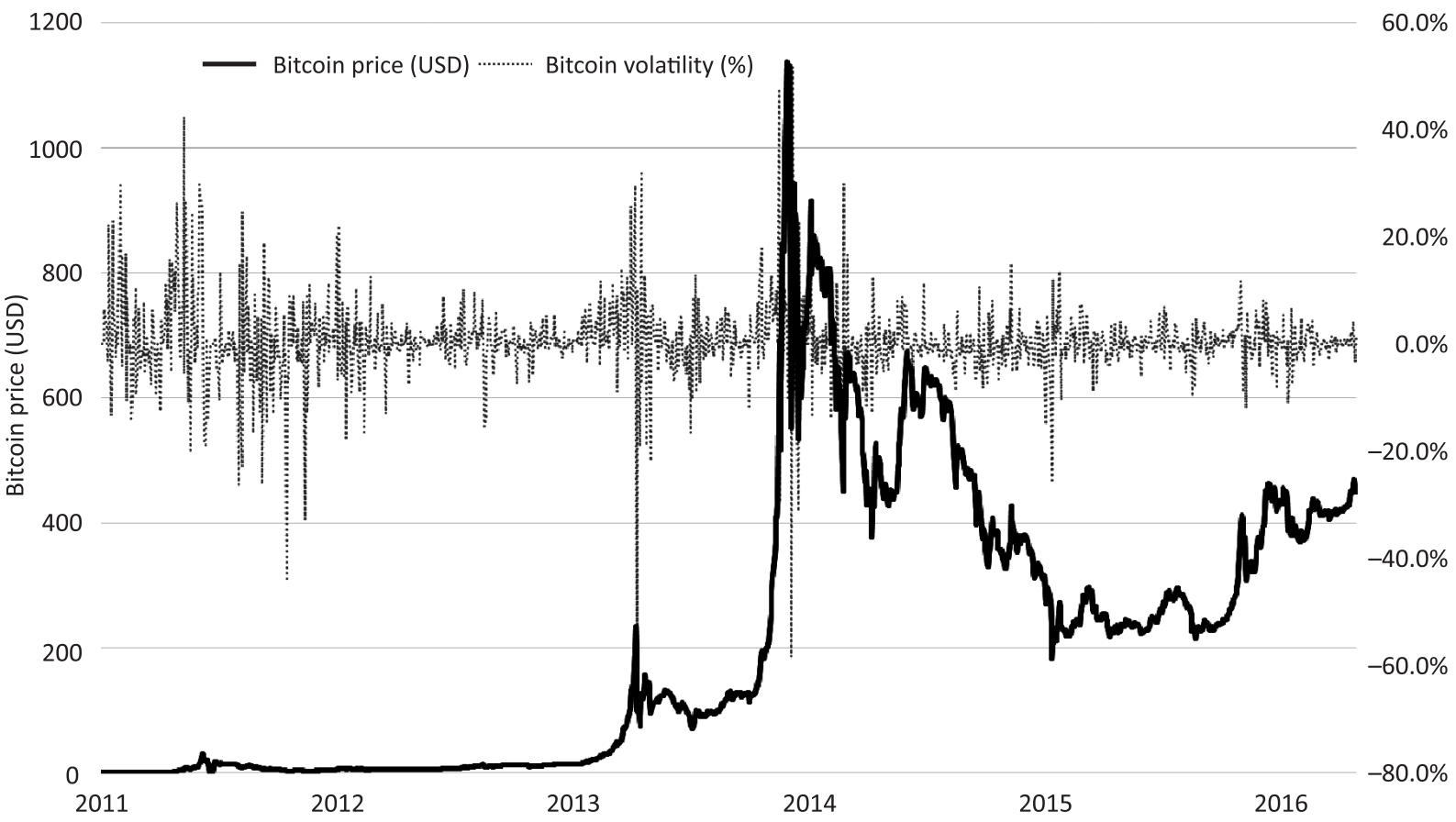

Figure 2. Bitcoin daily price returns and volatility from 2011 to 2016 
Table 2. Number of central bank monetary policy actions post policy board meetings

\begin{tabular}{|c|c|c|c|c|}
\hline Variable & FOMC & ECB & BOE & BOJ \\
\hline Increasing interest rates & 1 & 2 & 0 & 0 \\
\hline Reducing interest rates & 0 & 7 & 0 & 1 \\
\hline No change in interest rates & 46 & 54 & 69 & 80 \\
\hline Total & 47 & 63 & 69 & 81 \\
\hline Increasing quantitative easing & 5 & 4 & 3 & 11 \\
\hline Decreasing quantitative easing & 7 & 0 & 0 & 0 \\
\hline No change in quantitative easing & 33 & 58 & 66 & 70 \\
\hline Withdrawing quantitative easing & 2 & 1 & 0 & 0 \\
\hline Total & 33 & 63 & 69 & 81 \\
\hline
\end{tabular}

and Figure 2. It must be noted that bitcoin data is currently unavailable prior to 2010 , therefore the analysis is only presented thereafter. In Table 2 , we can see that there are, however, some central banks that have not taken particular policy responses in the sample period. For example, the FOMC and the Governing Board of the ECB were the only committees to increase interest rates during the sample period and the FOMC were the only committee to decrease quantitative easing.

We utilize an OLS model to estimate the effect of a number of variables on bitcoin returns. Let $r_{t}$ represent the domestic stock exchange return of country $i$ at time $t$. Our OLS model is then specified as follows:

$$
\begin{aligned}
& r_{i, t}=\beta_{0}+\beta_{1} \cdot r_{i, t-1}+\beta_{2} \cdot r_{i, E R_{t}}+\beta_{3} \cdot r_{S \& P_{t}}+ \\
& +\beta_{4} \cdot r_{E S T X_{t}}+\beta_{5} \cdot r_{G o l d_{t}}+\beta_{6} \cdot r_{W T I_{t}}+\beta_{7} \cdot r_{M_{t}}+ \\
& +\beta_{8} \cdot r_{W_{t}}+\beta_{9} \cdot r_{T_{t}}+\beta_{10} \cdot r_{F_{t}}+\mu_{t}
\end{aligned}
$$

where $r_{i, E R_{t}}$ represents the weighted exchange rate index return of country $i$. $r_{S \& P_{t}}$ and $r_{E S T X_{t}}$ are UK and European market proxies, representing the returns of the S\&P500 and EUROSTOXX indices,

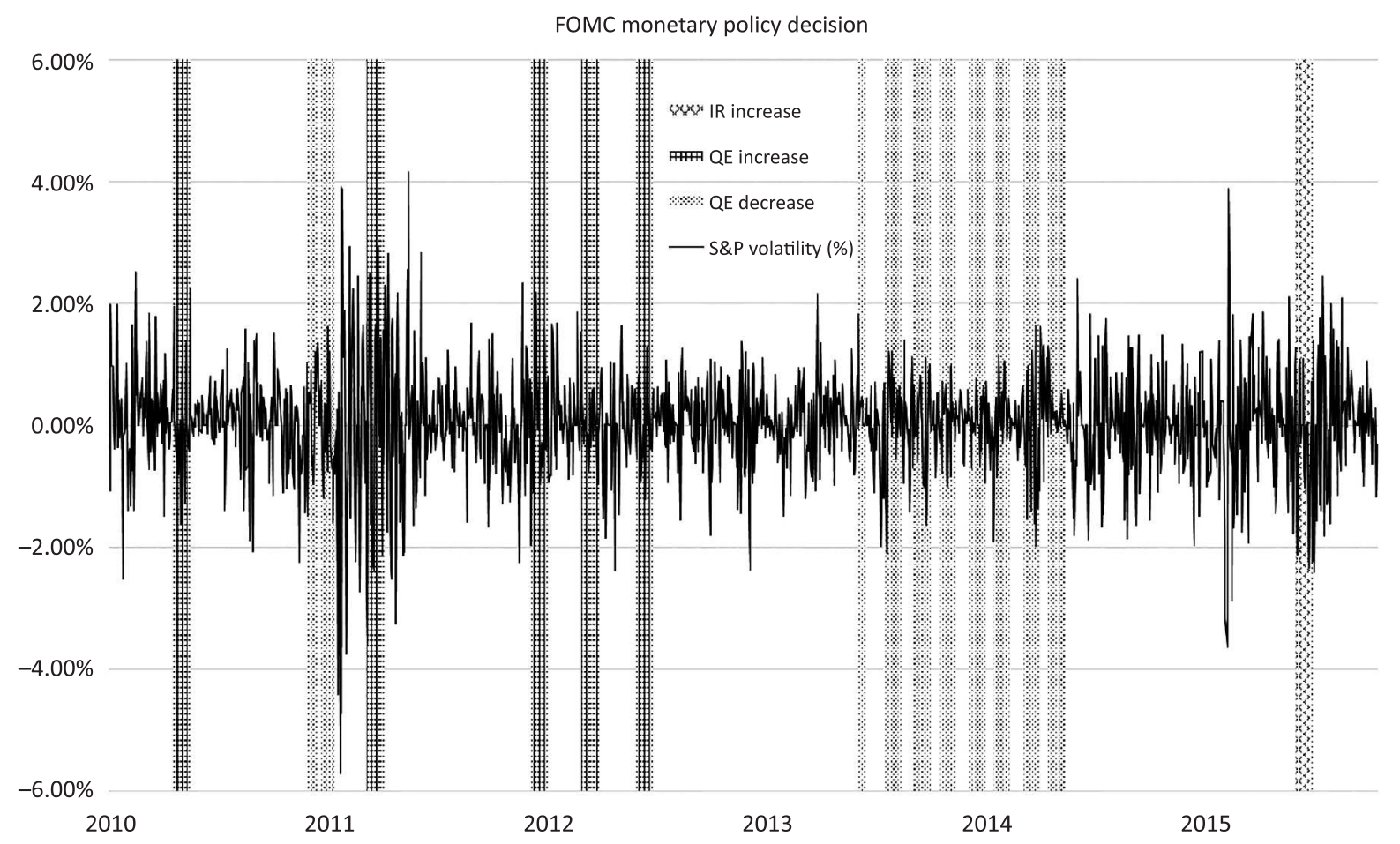

Note: this figure presents the daily return volatility of the domestic exchanges of the United States with monetary policy decisions included as the shaded region.

Figure 3a. Central bank monetary policy actions and domestic stock market volatility (2010-2016), the United States 


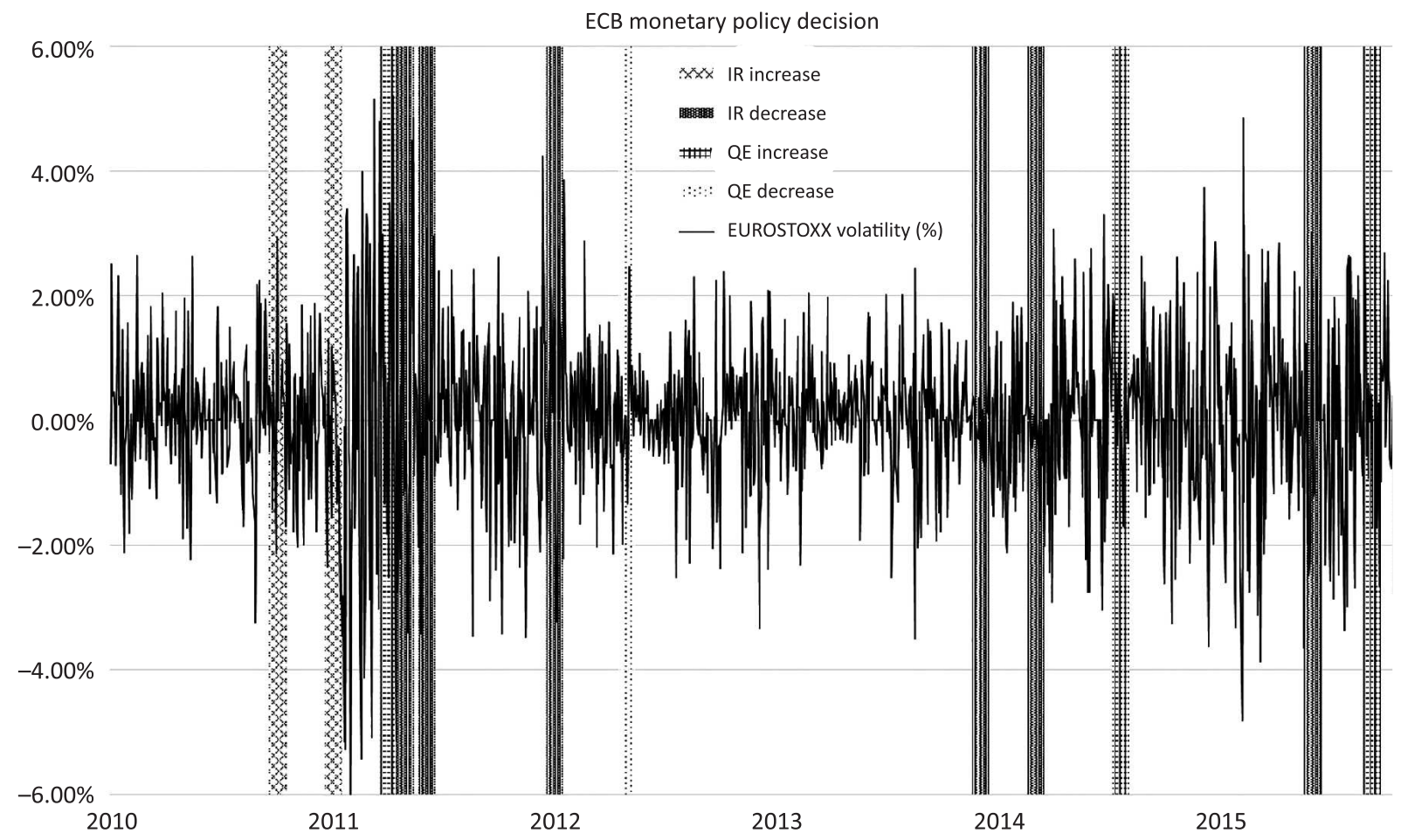

Note: this figure presents the daily return volatility of the domestic exchanges of Europe with monetary policy decisions included as the shaded region.

Figure 3b. Central bank monetary policy actions and domestic stock market volatility (2010-2016), Europe

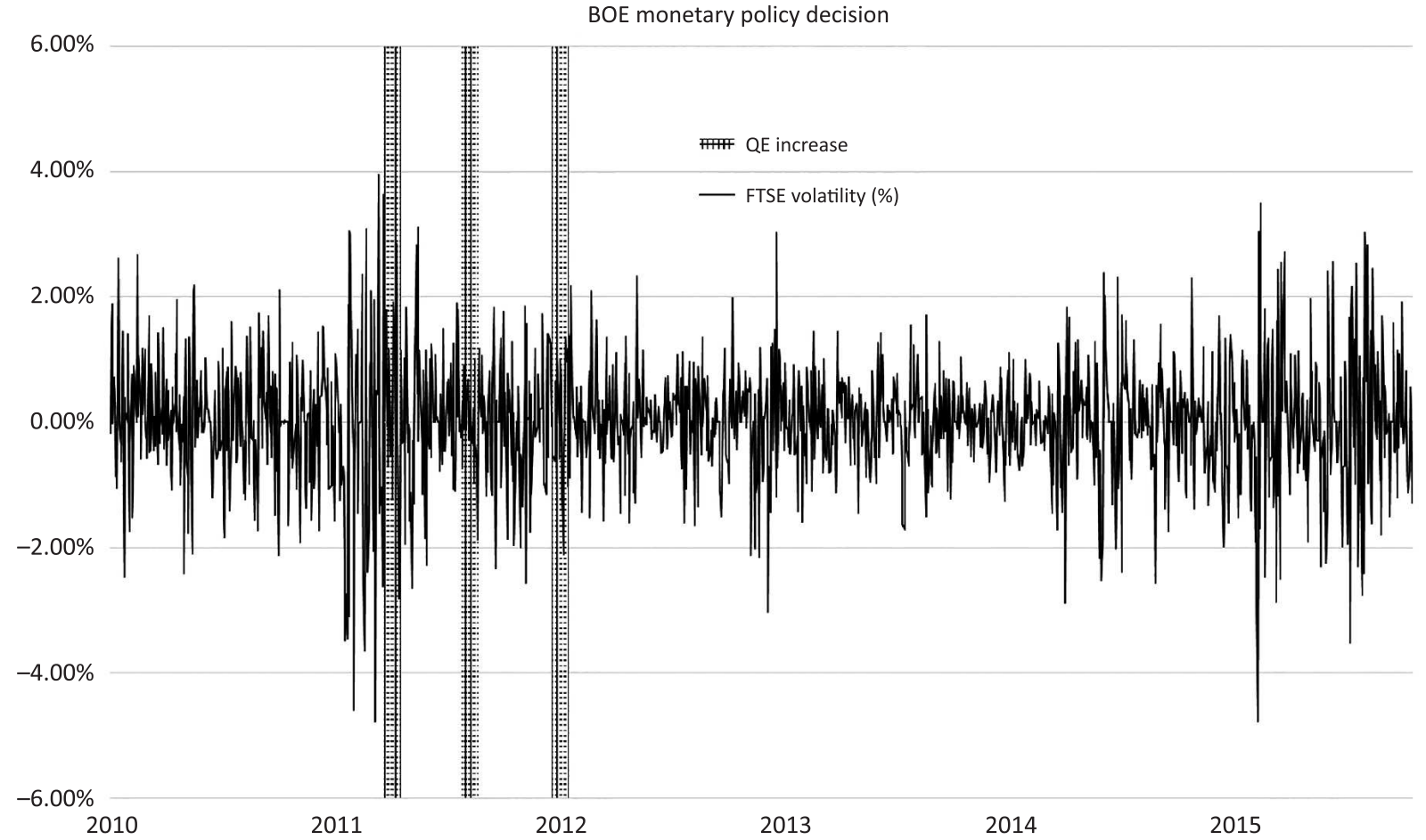

Note: this figure presents the daily return volatility of the domestic exchanges of the United Kingdom with monetary policy decisions included as the shaded region.

Figure 3c. Central bank monetary policy actions and domestic stock market volatility (2010-2016), United Kingdom 


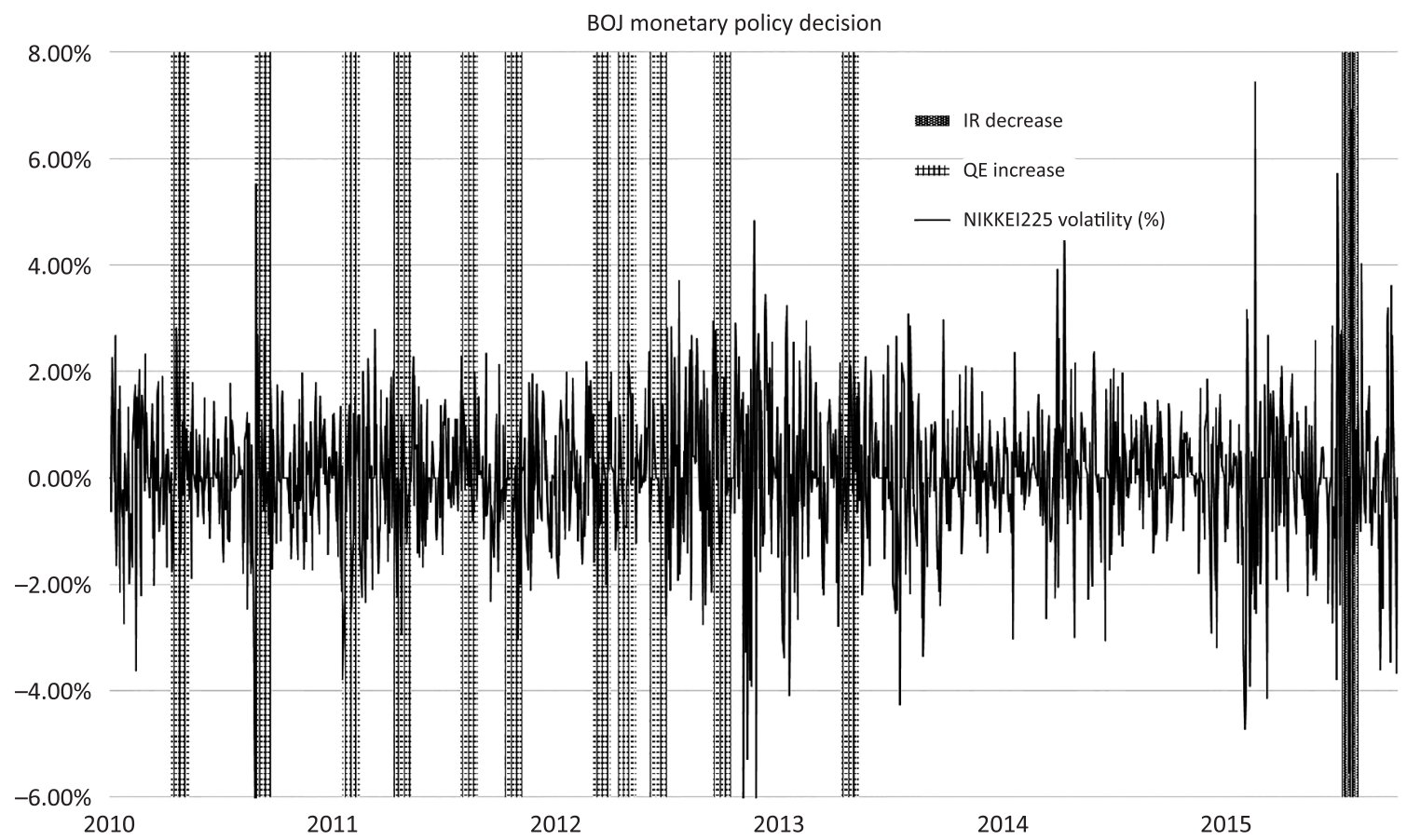

Note: this figure presents the daily return volatility of the domestic exchanges of Japan with monetary policy decisions included as the shaded region.

Figure 3d. Central bank monetary policy actions and domestic stock market volatility (2010-2016), Japan

respectively. $r_{\text {Gold }}$ and $r_{W T I_{t}}$ are commodity proxies representing gold spot price and crude oil returns, respectively. $r_{M_{t}}, r_{W_{t}}, r_{T_{t}}$ and $r_{F_{t}}$ are day-of-theweek dummy variables. $\mu_{t}$ is an ii $d$ error term. Bitcoin returns have been shown to exhibit volatility variability (Enders, 2010), indicating that the generalized autoregressive conditional heteroskedasticity, GARCH, specification (Bollerslev, 1986) is suitable for modelling. This is further confirmed by Engle's Lagrange multiplier test, which indicates the presence of a strong ARCH effect in the residuals of first differenced logged bitcoin price (Dyhrberg, 2015). We follow the existing literature by using a GARCH (1.1) specification, which takes the following form:

$$
\begin{aligned}
& r_{i, \mathrm{t}}=\gamma_{0}+\gamma_{1} \cdot r_{i, t-1}+\gamma_{2} \cdot r_{i, E R_{t}}+\gamma_{3} \cdot r_{S \& P_{t}}+ \\
& +\gamma_{4} \cdot r_{E S T X_{t}}+\gamma_{5} \cdot r_{G o l d_{t}}+\gamma_{6} \cdot r_{W T I_{t}}+\gamma_{7} \cdot r_{M_{t}}+ \\
& +\gamma_{8} \cdot r_{W_{t}}+\gamma_{9} \cdot r_{T_{t}}+\gamma_{10} \cdot r_{F_{t}}+\xi_{i, t},
\end{aligned}
$$

with variance equation:

$$
\sigma_{t}^{2}=\alpha_{0}+\alpha_{1} \cdot \varepsilon_{t-1}^{2}+\beta_{1} \cdot \sigma_{t-1}^{2}+\delta_{\text {policy }_{n_{t}}},
$$

where $\delta_{\text {policy }_{n_{t}}} \delta_{\text {policy }_{t}}$ represents a policy announcement by one of the respective central banks.

\section{EMPIRICAL RESULTS}

Table 3 reports the results of the OLS estimation and GARCH (1.1) estimations regarding the central bank's interest rate decisions and the bitcoin volatility estimates. In the OLS estimation, the variables of market risk, as measured by the trade-weighted exchange rate, the S\&P500 index, spot gold and the spot WTI price, are all positive and statistically significant. The EUROSTOXX 50 index variable is found to be negative and significant. Moreover, the results show that exchange rates explain a greater proportion of bitcoin's returns compared to stock market and commodity returns (although spot gold is significantly higher than the alternatives). The suitability of the regression estimates is examined using an ARCH test. A rejection of the null hypothesis would indicate that the squared residuals in equation (1) contain autocorrelation or heteroscedasticity. The first column of Table 3 reports the results of the ARCH test. Unsurprisingly, a residual serial correlation is present at the index level.

The estimated GARCH (1.1) parameters of the conditional return model for interest rates are also

9 Tuesday is omitted to avoid a dummy variable trap. The specification proves robust to the omission of any other day of the week, and no change in the results was observed. 
Table 3. GARCH (1.1) results for interest rates adjustment effects on bitcoin daily returns

\begin{tabular}{|c|c|c|c|c|c|}
\hline \multirow[b]{2}{*}{ Variable } & \multirow{2}{*}{$\begin{array}{c}\text { OLS - Eq. (1) } \\
\text { 1. OLS }\end{array}$} & \multicolumn{4}{|c|}{ GARCH $(1,1)-$ Eq. (3) \& (4) } \\
\hline & & $\begin{array}{c}\text { 2. FOMC } \\
\text { interest } \\
\text { rate decisions }\end{array}$ & $\begin{array}{l}\text { 3. ECB interest } \\
\text { rate decisions }\end{array}$ & $\begin{array}{l}\text { 4. BOE } \\
\text { interest } \\
\text { rate decisions }\end{array}$ & $\begin{array}{l}\text { 5. BOJ interest } \\
\text { rate decisions }\end{array}$ \\
\hline \multicolumn{6}{|c|}{ Mean equation } \\
\hline \multirow{2}{*}{ Constant } & $0.0041^{* *}$ & $0.0001^{* * *}$ & $0.0001^{* * *}$ & $0.0001^{* * *}$ & 0.0000 \\
\hline & $(0.0017)$ & $(0.0000)$ & $(0.0000)$ & $(0.0000)$ & $(0.0000)$ \\
\hline \multirow{2}{*}{ Bitcoin $_{t-1}$} & $-0.0477^{* * *}$ & $0.0004^{*}$ & $0.0015^{* * *}$ & 0.0003 & $0.0016^{* * *}$ \\
\hline & $(0.0057)$ & $(0.0003)$ & $(0.0002)$ & $(0.0002)$ & $(0.0002)$ \\
\hline \multirow{2}{*}{ Exch. Rate $_{t}$} & $0.6029 *$ & $-0.0046^{* *}$ & $-0.0063^{* * *}$ & $-0.0048^{*}$ & $-0.0068^{* * *}$ \\
\hline & $(0.3606)$ & $(0.0018)$ & $(0.0024)$ & $(0.0019)$ & $(0.0020)$ \\
\hline \multirow{2}{*}{$\mathrm{S} \& \mathrm{P} 500_{t}$} & $0.2337 * *$ & -0.0013 & $-0.0036^{*}$ & $0.0018^{*}$ & -0.0023 \\
\hline & $(0.1321)$ & $(0.0015)$ & $(0.0020)$ & $(0.0011)$ & $(0.0020)$ \\
\hline \multirow{2}{*}{ EUROSTOXX $50_{t}$} & $-0.0479^{*}$ & $0.0018^{*}$ & $0.0035^{* * *}$ & $-0.0023^{* *}$ & $0.0043^{* * *}$ \\
\hline & $(0.0205)$ & $(0.0010)$ & $(0.0012)$ & $(0.0011)$ & $(0.0011)$ \\
\hline \multirow{2}{*}{ Spot Gold } & $0.3444^{*}$ & $-0.0025^{* *}$ & $-0.0030^{* * *}$ & 0.0002 & $-0.0033^{* * *}$ \\
\hline & $(0.2043)$ & $(0.0011)$ & $(0.0012)$ & $(0.0006)$ & $(0.0011)$ \\
\hline \multirow{2}{*}{ Spot WTI crude $_{t}$} & $0.0429^{* *}$ & 0.0002 & 0.0004 & 0.0000 & 0.0004 \\
\hline & $(0.0272)$ & $(0.0006)$ & $(0.0007)$ & $(0.0000)$ & $(0.0006$ \\
\hline \multirow{2}{*}{ Monday $_{t}$} & $-0.0124^{*}$ & $-0.0001^{* *}$ & 0.0000 & 0.0000 & 0.0000 \\
\hline & $(0.0073)$ & $(0.0000)$ & $(0.0000)$ & $(0.0000)$ & $(0.0000)$ \\
\hline \multirow{2}{*}{ Wednesday $_{t}$} & -0.0059 & $-0.0001^{* * *}$ & -0.0001 & $-0.0001^{* *}$ & 0.0000 \\
\hline & $(0.0066)$ & $(0.0000)$ & $(0.0001)$ & $(0.0000)$ & $(0.0000)$ \\
\hline \multirow{2}{*}{ Thursday $_{t}$} & $-0.0119 *$ & $-0.0001^{*}$ & -0.0001 & 0.0000 & 0.0000 \\
\hline & $(0.0071)$ & $(0.0000)$ & $(0.0000)$ & $(0.0000)$ & $(0.0000)$ \\
\hline \multirow{2}{*}{ Friday $_{t}$} & $-0.0146^{* *}$ & -0.0001 & 0.0000 & -0.0001 & 0.0000 \\
\hline & $(0.0064)$ & $(0.0000)$ & $(0.0000)$ & $(0.0000)$ & $(0.0000)$ \\
\hline \multicolumn{6}{|c|}{ Variance equation } \\
\hline \multirow{2}{*}{ Constant } & - & $0.0003^{* * *}$ & $0.0001^{* * * *}$ & $0.0004^{* * *}$ & $0.0000^{* * *}$ \\
\hline & & $(0.0001)$ & $(0.0000)$ & $(0.0001)$ & $(0.0000)$ \\
\hline \multirow{2}{*}{$\mathrm{ARCH}$} & - & $0.1340^{* * *}$ & $0.0815^{* * *}$ & $0.0682^{* * *}$ & $0.0709^{* * *}$ \\
\hline & & $(0.0129)$ & $(0.0071)$ & $(0.0064)$ & $(0.0064)$ \\
\hline \multirow{2}{*}{ GARCH } & - & $0.8336^{* * *}$ & $0.8935^{* * *}$ & $0.9039^{* * *}$ & $0.9008^{* * *}$ \\
\hline & & $(0.0076)$ & $(0.0036)$ & $(0.0032)$ & $(0.0291)$ \\
\hline \multirow{2}{*}{ Interest rate increase $_{t}$} & - & $0.016^{* *}$ & $0.0058^{*}$ & - & - \\
\hline & & $(0.0072)$ & $(0.0038)$ & & \\
\hline \multirow{2}{*}{ Interest rate decrease ${ }_{t}$} & - & - & $-0.0015^{*}$ & - & $-0.0273^{* * *}$ \\
\hline & & & $(0.0009)$ & & $(0.0080)$ \\
\hline \multirow{2}{*}{ Interest rate no change ${ }_{t}$} & - & $0.0189^{* * *}$ & $0.0075^{* * *}$ & 0.0141 & -0.0005 \\
\hline & & $(0.0030)$ & $(0.0004)$ & $(0.0130)$ & $(0.0004)$ \\
\hline Adjusted $R^{2}$ & 0.1965 & - & - & - & - \\
\hline $\mathrm{ARCH}(1.1)$ & $52.551^{* * *}$ & - & - & - & - \\
\hline Log-likelihood & - & 2278.446 & 2126.340 & 2271.597 & 2102.741 \\
\hline$\varkappa^{2}$ & - & 27.461 & 73.768 & 23.370 & 104.509 \\
\hline
\end{tabular}

Notes: Estimates in column 1 are based on the OLS methodology reported in Eq. (1). Estimates in columns 2-5 are based on the GARCH (1.1) methodology in Eq. (3) and Eq. (4). Coefficients in parentheses indicate the standard errors. ${ }^{* * *},{ }^{* *}$ and ${ }^{*}$ indicate the significance level at the $1 \%, 5 \%$ and $10 \%$ levels, respectively. 
Table 4. GARCH (1.1) results for Quantitative Easing (QE) adjustment effects on bitcoin daily returns

\begin{tabular}{|c|c|c|c|c|}
\hline \multirow{2}{*}{ Variable } & \multicolumn{4}{|c|}{ GARCH (1.1) - Eq. (3) \& (4) } \\
\hline & FOMC QE decision & ECB QE decision & BOE QE decision & BOJ QE decision \\
\hline \multicolumn{5}{|c|}{ Mean equation } \\
\hline \multirow{2}{*}{ Constant } & $0.0001^{* * *}$ & 0.0000 & $0.0001^{* * *}$ & 0.0000 \\
\hline & $(0.0000)$ & $(0.0000)$ & $(0.000)$ & $(0.0000)$ \\
\hline \multirow{2}{*}{ Bitcoin $_{t-1}$} & 0.0004 & $0.0014^{* * *}$ & $0.0004^{*}$ & $0.0013^{* * *}$ \\
\hline & $(0.0029)$ & $(0.0002)$ & $(0.0003)$ & $(0.0002)$ \\
\hline \multirow{2}{*}{ Exch. Rate $_{t}$} & $-0.0046^{* *}$ & $-0.0057^{* *}$ & $-0.0040^{* *}$ & $-0.0089^{* * *}$ \\
\hline & $(0.0018)$ & $(0.0023)$ & $(0.0020)$ & $(0.0020)$ \\
\hline \multirow{2}{*}{$\mathrm{S} \& \mathrm{P} 500_{t}$} & -0.0013 & -0.0032 & $-0.0032^{*}$ & -0.0010 \\
\hline & $(0.0015)$ & $(0.0022)$ & $(0.0017)$ & $(0.0018)$ \\
\hline \multirow{2}{*}{ EUROSTOXX $50_{t}$} & $0.0017^{*}$ & $0.0034^{* * *}$ & $0.0020^{* *}$ & $0.0035^{* * *}$ \\
\hline & $(0.0010)$ & $(0.0012)$ & $(0.0010)$ & $(0.0012)$ \\
\hline \multirow{2}{*}{ Spot Gold $_{t}$} & $-0.0026^{* *}$ & $-0.0029^{* *}$ & $-0.0026^{* *}$ & $-0.0024^{* *}$ \\
\hline & $(0.0011)$ & $(0.0012)$ & $(0.0017)$ & $(0.0012)$ \\
\hline \multirow{2}{*}{ 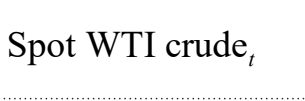 } & 0.0002 & 0.0001 & 0.0002 & 0.0003 \\
\hline & $(0.0006)$ & (0.0008) & $(0.0006)$ & $(0.0008)$ \\
\hline \multirow{2}{*}{ Monday $_{t}$} & $-0.0001^{* *}$ & 0.0000 & $-0.0001^{* *}$ & $-0.0001^{*}$ \\
\hline & $(0.0000)$ & $(0.0000)$ & $(0.0000)$ & $(0.0000)$ \\
\hline \multirow{2}{*}{ Wednesday $_{t}$} & $-0.0001^{* * *}$ & -0.0001 & $-0.0009^{*}$ & -0.0001 \\
\hline & $(0.0000)$ & $(0.0000)$ & $(0.0000)$ & $(0.0000)$ \\
\hline \multirow{2}{*}{ Thursday $_{t}$} & $-0.0001^{* * *}$ & 0.0000 & -0.0001 & 0.0000 \\
\hline & $(0.0000)$ & $(0.0000)$ & $(0.0000)$ & $(0.0000)$ \\
\hline \multirow{2}{*}{ Friday $_{t}$} & $0.0001^{* * *}$ & 0.0000 & $-0.0001^{*}$ & $0.0001^{* *}$ \\
\hline & $(0.0000)$ & $(0.0000)$ & $(0.0000)$ & $(0.0000)$ \\
\hline \multicolumn{5}{|c|}{ Variance equation } \\
\hline \multirow{2}{*}{ Constant } & $0.0001 * * *$ & $0.0001^{* * *}$ & $0.0001^{* * *}$ & $0.0002^{* * *}$ \\
\hline & $(0.0000)$ & $(0.0000)$ & $(0.001)$ & $(0.001)$ \\
\hline \multirow{2}{*}{$\mathrm{ARCH}$} & $0.1512^{* * *}$ & $0.0692 * * *$ & $0.1732^{* * *}$ & $0.0732 * * *$ \\
\hline & $(0.0161)$ & $(0.0064)$ & $(0.0164)$ & $(0.0067)$ \\
\hline \multirow{2}{*}{ GARCH } & $0.8141^{* * *}$ & $0.9019 * * *$ & $0.7742 * * *$ & $0.8993^{* * *}$ \\
\hline & $(0.0095)$ & $(0.0032)$ & $(0.0122)$ & $(0.0033)$ \\
\hline \multirow{2}{*}{$\mathrm{QE}_{\text {increase }_{t}}$} & $0.0066^{*}$ & $0.0086^{* * *}$ & $0.0206^{* * *}$ & $0.0060^{* * *}$ \\
\hline & $(0.0037)$ & $(0.0007)$ & $(0.0013)$ & $(0.0006)$ \\
\hline \multirow{2}{*}{ QE decrease ${ }_{t}$} & $0.0185^{* * *}$ & - & - & - \\
\hline & $(0.0030)$ & & & \\
\hline \multirow{2}{*}{$\mathrm{QE}_{\text {withdrawal }}$} & $0.0154^{* * *}$ & $-0.0148^{* * *}$ & - & - \\
\hline & $(0.0059)$ & $(0.0042)$ & & \\
\hline \multirow{2}{*}{$\mathrm{QE} \mathrm{no} \mathrm{change}_{t}$} & $0.0190^{* * *}$ & $0.0051^{* * *}$ & $-0.0087^{* * *}$ & $-0.0045^{* * *}$ \\
\hline & $(0.0028)$ & $(0.0004)$ & $(0.0030)$ & (0.0009) \\
\hline Log-likelihood & 2280.333 & 2117.727 & 2278.995 & 2110.138 \\
\hline$x^{2}$ & 26.139 & 68.981 & 25.051 & 14.004 \\
\hline
\end{tabular}

Notes: Coefficients in parentheses indicate the standard errors. ${ }^{* * *}{ }^{* *}$ and ${ }^{*}$ indicate the significance level at the $1 \%, 5 \%$ and $10 \%$ levels, respectively. 
presented in Table 3. In the conditional variance equation, the intercept term $\left(\alpha_{0}\right)$ is positive and statistically significant in all cases, indicating that a significant time-invariant component in the return generating process. Both the ARCH parameter $\alpha_{1}$ and GARCH parameter $\beta$ satisfy the nonnegativity conditions ${ }^{10}$.

A highly statistically significant negative relationship between the returns of bitcoin and the included exchange rates is observed in Table 3. Only the ECB and BOE-based models present a significant relationship between the returns of bitcoin, and US stock market returns (as measured by the S\&P500). All models present significantly positive relationships with European stock returns (with the exception of the BOE which is significantly negative). The FOMC, ECB and BOJ models present significantly negative returns with relation to spot gold prices and there are no significant findings from the inclusion of WTI in the interest rate GARCH (1.1) methodology. Day of the week effects are significant only in the US model, and show little significance in the three remaining monetary policy models. The variance equation indicates that the FOMC decision to increase interest rates led to a corresponding $1.60 \%$ increase in the volatility of bitcoin - the ECB decision was insignificant (the $\mathrm{BOE}$ and $\mathrm{BO}$ ) made no increases in interest rates during the period).

The ECB and $\mathrm{BOJ}$ decrease in interest rates during the period led to a corresponding decrease of $0.15 \%$ and $2.73 \%$ in volatility, respectively. There are multiple occasions in which a decision not to change rates was taken in each of the four jurisdictions. The most substantial finding states that there was a significant volatility impact from FOMC and ECB rate decisions, indicating that bitcoin returns were indeed influenced by the decisions of international policy makers. Returns volatility in the period following interest rate announcements increased by $1.89 \%$ (in the case of FOMC decisions) and $0.75 \%$ (ECB decisions). The BOE and BOJ volatility estimates in this regard are insignificant.

All quantitative easing announcements by the four central banks in our sample are found to have a significant effect up on the return volatility of bitcoin. An increase in quantitative easing had a strong, significantly positive impact on return volatility. FOMC decisions increased volatility by $0.66 \%$, ECB decisions by $0.86 \%$, BOJ decisions by $0.60 \%$ and BOE decisions to implement quantitative easing increased return volatility by $2.06 \%$ after being controlled for international effects. The FOMC was the only policy board to decrease quantitative easing, without withdrawal, which led to a significant decrease in bitcoin returns volatility of $1.48 \%$. Both the FOMC and ECB announced policies to withdraw their quantitative easing programes leading to significant impacts in both cases - the FOMC decision led to a $1.54 \%$ increase in volatility, while the ECB announcement led to a significant volatility reduction of $1.48 \%$. In addition to actual changes in quantitative easing, we include scenarios in which a central bank specifically mentioned that QE was being considered as an option, as this remains a significant departure from standard monetary policy. In these situation, the FOMC and ECB announcements increased volatility by $1.90 \%$ and $0.51 \%$, respectively, while BOE and BOJ statements led to a decrease in volatility of $0.87 \%$ and $0.45 \%$, respectively. These results provide further evidence of monetary policy announcements generating significant return volatility effects for bitcoin, echoing the sentiments of Rangel (2010) with regard to broader macroeconomic variables generating volatility changes in cryptocurrencies.

\section{CONCLUSION}

This study examines the effects of monetary policy decisions made by the FOMC, ECB, BOE and BOJ on bitcoin returns by employing both OLS and GARCH estimation models. Application of time-varying risk models also enabled us to introduce volatility of exchange rates, stock markets and commodities, (in the form of spot gold and spot WTI prices) into the cryptocurrency return volatility generating process.

10 The GARCH parameter is significantly greater that the ARCH, implying that the volatility of each European stock index is more sensitive to its own lagged values than to new surprises (the effects of a previous period's forecast variance are more persistent). The sum of the $\alpha_{1}$ and $\beta$ parameters are close to unity in all cases, indicating that shocks to bitcoin returns have highly persistent effects and the response of volatility decays at a slower rate. 
Using a GARCH (1.1) methodology, we find evidence of significant return volatility, generated both by decisions to adjust interest rates and to introduce quantitative easing made by the central banks of the US, EU, UK and Japan. Quantitative easing decisions are found to have generated the most significant influence. FOMC interest rate increases led to a significantly positive increase in bitcoin volatility, while reductions in ECB and $\mathrm{BOJ}$ interest rates corresponded with reduced levels of bitcoin volatility. All QE announcements made by the four central banks had a strong significantly positive effect on bitcoin returns volatility.

The finding that bitcoin volatility is influenced by both interest rate adjustments and QE announcements is somewhat surprising, and has a number of implications for a supposedly decentralized currency. While the nature and workings of bitcoin are decentralized and free from government influence, our findings suggest that the digital asset itself is not completely independent of government actions and, in its current state, remains vulnerable to policy announcements. This finding holds a number of implications both for bitcoin users, and for investors using bitcoin as a diversification tool (Brière et al., 2015). In addition, our results contribute to the ongoing debate regarding the classification of bitcoin as a particular asset class. Our findings suggest that bitcoin shares a number of characteristics with both currency pairs, and commodities such as gold, adding further weight to the suggestion of Dyhrberg (2016) that bitcoin is in itself a unique asset class, falling somewhere between a traditional store-of-value asset (such as gold) and an actual currency (US dollars).

\section{REFERENCES}

1. Anzuini, A., Lombardi, M. J., Pagano, P. (2013). The impact of monetary policy shocks on commodity prices. International Journal of Central Banking, 9(3), 119-144. Retrieved from http://www.ijcb.org/ journal/ijcb13q3a4.pdf

2. Belgacem, A., \& Lahini, A. (2012). More on the impact of US macroeconomic announcements: Evidence from French and German stock markets' volatility. Economics Bulletin, 32(2), 1509-1526. Retrieved from http://data.leo-univ-orleans.fr/ media/seminars/130/WP_130.pdf

3. Bernanke, B. S., \& Kuttner, K. N. (2005). What explains the stock market's reaction to Federal Reserve policy? Journal of Finance, 60, 1221 1257. http://dx.doi.org/10.1111/ j.1540-6261.2005.00760.x

4. Birz, G., \& Lott Jr., R. J. (2011). The effect of macroeconomic news on stock returns: New evidence from newspaper coverage. Journal of Banking and Finance, 35, 2791-2800. https://doi.org/10.1016/j.jbankfin.2011.03.006

5. Bollerslev, T. (1986). Generalized Autoregressive Conditional Heteroskedasticity. Journal of Econometrics, 31, 307-327. https://doi.org/10.1016/03044076(86)90063-1

6. Bollerslev, T., Chou, R. Y., Kroner, K. F. (1992). ARCH modelling in finance: A review of the theory and empirical evidence. Journal of Econometrics, 52(1), 5-59. https://doi.org/10.1016/03044076(92)90064-X

7. Bomfim, A. N. (2003). Pre-announcement effects, news effects, and volatility: Monetary policy and the stock market. Journal of Banking and Finance, 27, 133-151. https://doi.org/10.1016/S03784266(01)00211-4

8. Brière, M., Oosterlinck, K., \& Szafarz, A. (2015). Virtual currency, tangible return: Portfolio diversification with bitcoin. Journal of Asset Management, 16(6), 365-373. https://doi.org/10.1057/ jam. 2015.5

9. Cheah, T. E., \& Fry, J. (2014). Speculative Bubbles in Bitcoin markets? An empirical investigation into the fundamental value of Bitcoin. Economic Letters, 13, 32-36. https://doi. org/10.1016/j.econlet.2015.02.029

10. Chen, Y-C, Rogoff, K. (2003). Commodity currencies. Journal of
International Economics, 60(1), 133 160. https://doi.org/10.1016/S00221996(02)00072-7

11. Chu, J., Nadarajah, S., \& Chan, S. (2015). Statistical Analysis of the Exchange Rate of Bitcoin. PLoS ONE, 10(7), 1-27. https://doi. org/10.1371/journal.pone.0133678

12. Chulia, H., Martens, M., \& van Dijk, D. (2010). Asymmetric effects of federal funds target rate changes on S\&P100 stock returns, volatilities and correlations. Journal of Banking and Finance, 34, 834-839. https://doi. org/10.1016/j.jbankfin.2009.09.012

13. Cody, B. J., Mills, L. O. (1991). The role of commodity prices in formulating monetary policy. The Review of Economics and Statistics, 73(2), 358-365. https://doi. org/10.2307/2109529

14. D’Amico, S., English, W., LópezSalido, D., \& Nelson, E. (2012). The Federal Reserve's Large-Scale Asset Purchase Programmes: Rationale and Effects. The Economic Journal, 122, 415-446. https://doi.org/10.1111/j.14680297.2012.02550.x

15. Dwyer, G. P. (2015). The economics of Bitcoin and other 
similar private digital currencies. Journal of Financial Stability, 17, 81-91. https://doi.org/10.1016/j. jfs.2014.11.006

16. Dyhrberg, A. H. (2016). Bitcoin, gold and the dollar-A GARCH volatility analysis. Finance Research Letters, 16, 85-92. https:// doi.org/10.1016/j.frl.2015.10.008

17. Égert, B., \& Kocenda, E. (2013). The impact of macro news and central bank communication on emerging European forex markets. Economic Systems, 38, 73-88. https://doi.org/10.1016/j.ecosys.2013.01.004

18. Engle, R. F. (1982). Autoregressive conditional heteroscedasticity with estimates of the variance of United Kingdom inflation. Econometrica, 50(4), 987-1007. https:// doi.org/10.2307/1912773

19. Eun, S. C., \& Shim, S. (1989). International Transmission of Stock Market Movements. The Journal of Financial and Quantitative Analysis, 24(2), 241-256. https:// doi.org/10.2307/2330774

20. European Central Bank (2012). Virtual currency schemes. ECB Bulletin, October, 1-55.

21. Geman, H., Madan, D., \& Yor, M. (2000). Asset prices are Brownian motion: only in business time, Quantitative Analysis in Financial Markets (pp. 103-146). New York: World Scientific, River Edge. https://doi. org/10.1142/9789812810663_0004

22. Glick, R., \& Leduc, S. (2012). Central bank announcements of asset purchases and the impact on global financial and commodity markets. Journal of International Moneyand Finance, 31, 2078-2101. https://doi.org/10.1016/j.jimonfin.2012.05.009

23. Harwick, C. (2015). Cryptocurrency and the Problem of Intermediation. The Independent Review, 20(4), 569-588. Retrieved from http:// www.independent.org/pdf/tir/ tir_20_04_05_harwick.pdf
24. Hayek, F. A. (1977). A Free-Market Monetary System. Journal of Libertarian Studies, 3(1), 1-8.

25. Hayek, F. A. (1990). Denationalization of Money - The Argument Refined ( $3^{\text {rd }}$ ed.). Alabama: The Institute of Economic Affairs.

26. Joyce, M., Lasaosa, A., Stevens, I., \& Tong, M. (2010). The Financial Market Impact of Quantitative Easing (Bank of England Working Paper, No. 393). Retrieved from https://www.stlouisfed.org/ /media/Files/PDFs/Press\%20Releases/2011-06-30/Joyce_Paper.pdf

27. Karlstrom, H. (2014). Do libertarians dream of electric coins? The material embeddedness of Bitcoin. Distinktion: Scandinavian Journal of Social Theory, 15(1), 23-36. https://doi.org/10.1080/160091 0X.2013.870083

28. Kristoufek, L. (2015). What are the main drivers of the Bitcoin price? Evidence from wavelet coherence analysis. PloS one, 10(4), 1-15. https:// doi.org/10.1371/journal. pone. 0123923

29. Kroll, J. A., Davey, I. C., \& Felten, E. W. (2013). June. The economics of Bitcoin mining, or Bitcoin in the presence of adversaries. In Proceedings of WEIS. Retrieved from http://www.thebitcoin.fr/ wp-content/uploads/2014/01/ The-Economics-of-Bitcoin-Mining-or-Bitcoin-in-the-Presenceof-Adversaries.pdf

30. Lo, S., \& Wang, C. (2014). Bitcoin as Money. Federal Reserve Bank of Boston. Current Policy Perspectives, 14(4), 1-28. Retrieved from https://www.bostonfed.org/-/media/Documents/ Workingpapers/PDF/cpp1404.pdf

31. Lobo, B. J. (2002). Interest rate surprises and stock prices. Financial Review, 37, 73-92. https://doi. org/10.1111/1540-6288.00005

32. Lobo, B. J. (2000). Asymmetric effects of interest rate changes on stock prices. The Financial
Review, 35, 125-144. https://doi. org/10.1111/j.1540-6288.2000. tb01424.x

33. Luther, W. J. (2015). Cryptocurrencies, network effects, and switching costs. Contemporary Economic Policy, 34(3), 553571. https://doi.org/10.1111/ coep. 12151

34. Marian, O. (2013). Are cryptocurrencies super tax havens? Michigan Law Review First Impressions, 38(1), 1-11. Retrieved from https://repository.law.umich. edu/mlr_fi/vol112/iss1/2

35. Meaning, J., \& Zhu, F. (2011). The impact of recent central bank asset purchase programes. Bank of International Settlements Quarterly Review, December, 7383. Retrieved from http://www.bis. org/publ/qtrpdf/r_qt1112h.pdf

36. Mittal, S. (2012). Is Bitcoin Money? Bitcoin and Alternative Theories of Money. Bitcoin and Alternative Theories of Money, Harvard University, Law School, April 23.

37. Rangel, G. (2010).

Macroeconomic news, announcements, and stock market jump intensity dynamics. Journal of Banking and Finance, 35, 12631276. https://doi.org/10.1016/j. jbankfin.2010.10.009

38. Swartz, D. N. (2014). Bursting the Bitcoin Bubble: The case to regulate digital currency as a security or commodity. Tulane Journal of Technology and Intellectual Property, 17(1), 319-335. https://doi.or g/10.1080/13504851.2014.995359

39. Yelowitz, A., \& Wilson, M. (2015). Characteristics of Bitcoin users: an analysis of Google search data. Applied Economics Letters, 22(13), 1030-1036. Retrieved from http:// centerforfinancialstability.org/research/DavidYermack-Bitcoin.pdf

40. Yermack, D. (2013). Is Bitcoin a Real Currency? An economic appraisal (National Bureau of Economic Research Working Paper Series, No. 19747). 